\title{
TRICHOSCAPA KARAWAJEWI AND ITS SYNONYMS (HYMENOPTERA: FORMICIDAE)
}

\author{
BY WiLliaM L. BROWN, JR. \\ Department of Entomology \\ Cornell University \\ Ithaca, NY 14853
}

A recent loan from the Zoological Institute, Ukrainian Academy of Sciences, Kiev, Ukrainia, through the kindness of Dr. Alexander G. Radchenko, has allowed me for the first time to examine the type of Strumigenys emeryi Karawajew, which proves to be an example of the same species I later described as Smithistruma dubia. Since S. emeryi was preoccupied in Strumigenys, I had already given it the replacement name Strumigenys (Trichoscapa) karawajewi. The necessary synonymy follows.

\section{Trichoscapa karawajewi (new combination)}

Strumigenys (Cephaloxys) emeryi Karawajew, 1935, Treubia 15:106-108, fig. 25, queen, type locality Siak, Sumatra. Preoccupied.

Strumigenys (Trichoscapa) karawajewi Brown, 1948, Entomological News, Philadelphia, 59:44, replacement name.

Smithistruma (Smithistruma) dubia Brown, 1953, American Midland Naturalist, 50:122, worker, queen, type locality East Coast of Peleliu I., Palau Group. New synonym.

In the type from Kiev, the clypeus is broader than long. In addition, the larger hairs on the head are as arranged in other samples of this species, and are not restricted to two at cephalic midlength as depicted by Karawajew. Although I described S. dubia from atolls in the South Pacific, while $S$. karawajewi came from Sumatra, we now have samples of this species from numerous sites in New Guinea and the Solomons, Sulawesi, Luzon, Sabah, Manus, Truk, and Ponape, as well as Fiji. Because the limits of the shortmandibulate dacetite dacetine genera have grown very unclear as

Manuscript received 11 October 1994. 
many new species accumulated in this complex, I have left this species in Trichoscapa, where I placed it as a subgenus in those years when I still regarded that category worthwhile. As a name, Trichoscapa is old, and bids likely to survive the generic decimation that will be necessary in the next revision of the Dacetini. 

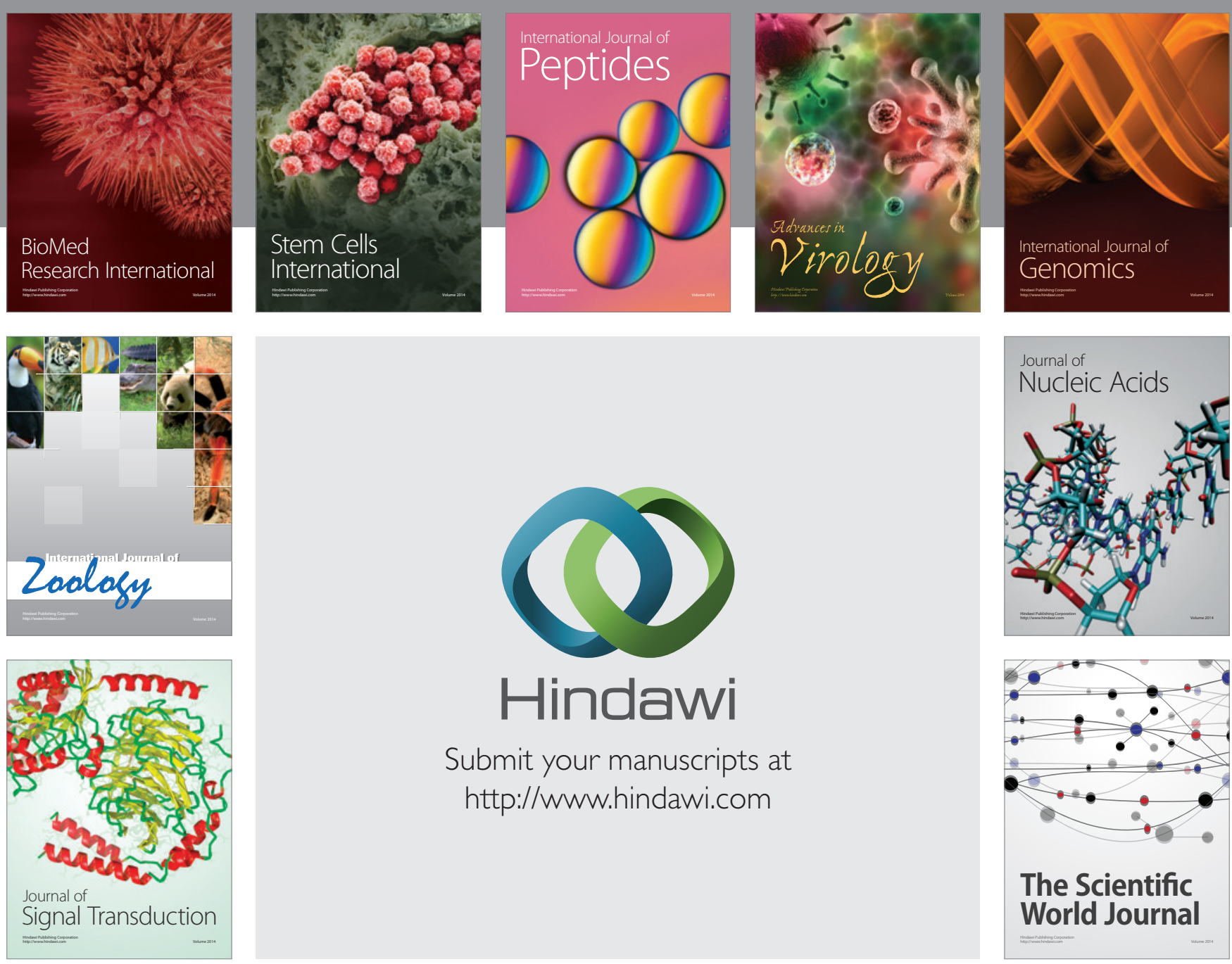

Submit your manuscripts at

http://www.hindawi.com
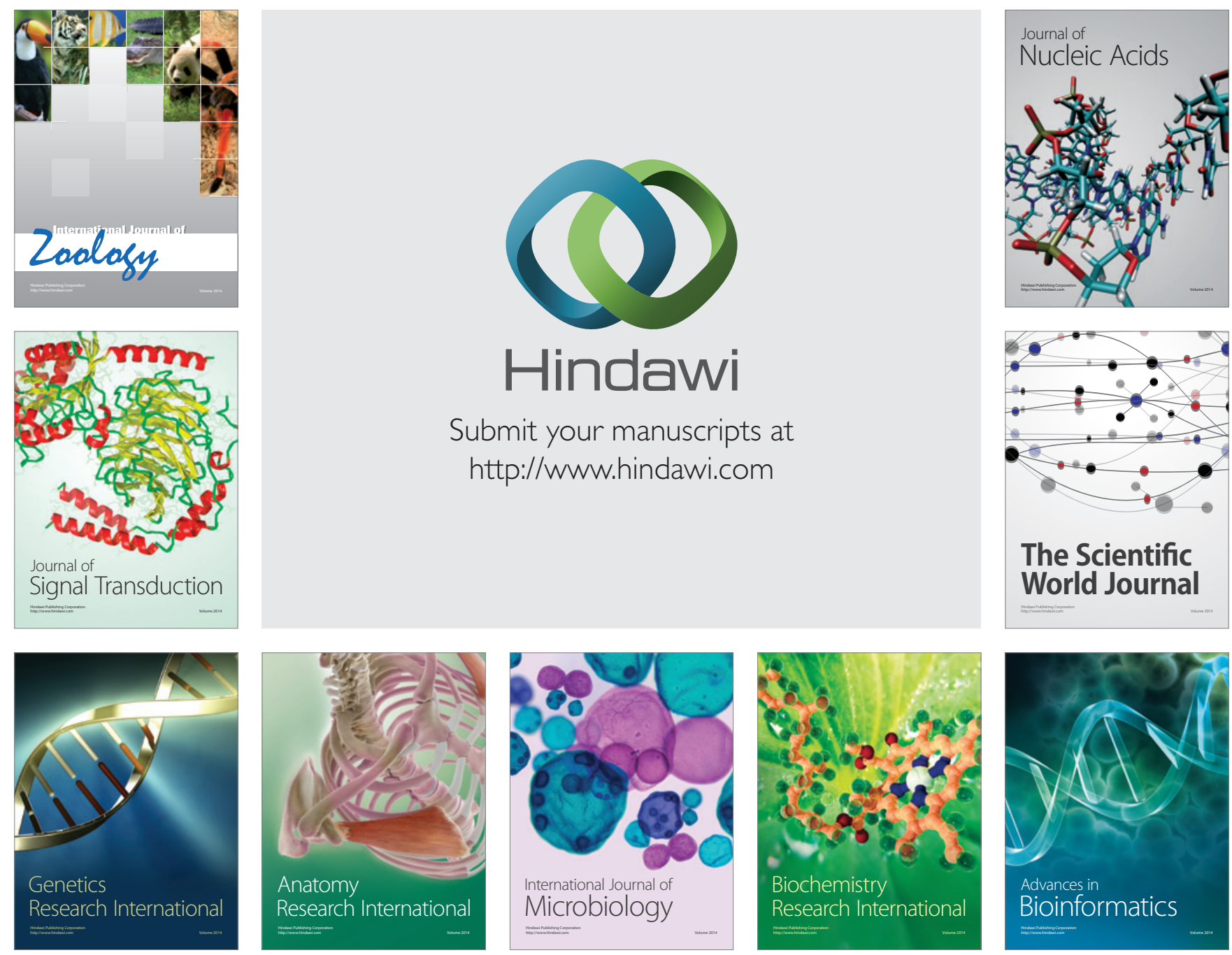

The Scientific World Journal
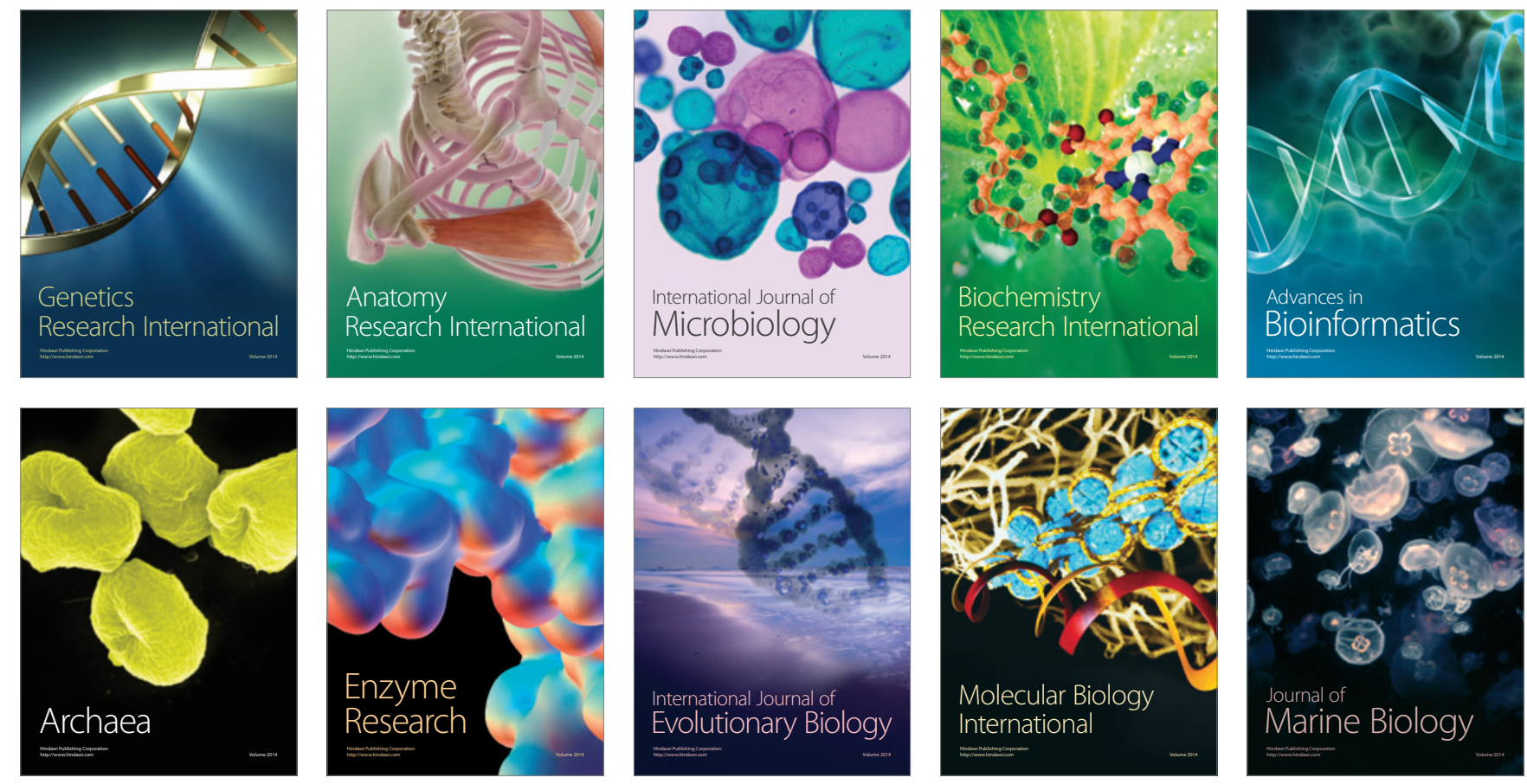